THE INFLUENCE OF ACCOUNTABILITY, SELF EFFICACY, AND TASK COMPLEXITY ON THE PERFORMANCE OF AUDIT JUDGEMENT VARIABLES INTERVENING EFFORT

\title{
PENGARUH AKUNTABILITAS, SELF EFFICACY, DAN KOMPLEKSITAS TUGAS TERHADAP KINERJA AUDIT JUDGEMENT VARIABEL INTERVENING EFFORT
}

\author{
Oleh: \\ Wisnu Saputra ${ }^{1)}$ dan Ali Sandy Mulya ${ }^{2)}$ \\ ${ }^{1)}$ Fakultas Ekonomi dan Bisnis Universitas Budi Luhur \\ Wisnubabehsaputra@gmail.com \\ ${ }^{2)}$ Fakultas Ekonomi dan Bisnis Universitas Budi Luhur \\ Alisandy@outlook.com
}

\begin{abstract}
Purpose of the study was to analyze the effect of Accountability, Self Efficcay, and Task Complexity, to Audit Judgement Performance is mediated by effort. The data used in the study were obtained from the Public Accounting Firm in Jakarta and registered in OJK (The Financial Services Authority). The data in this study were processed using Structural Equation Modeling (SEM) with statistical tests using Smart Partial Least Square (PLS). The object of research in this study is all auditors in KAP registered by OJK. This study uses a survey research method with primary data collection using a questionnaire. The results show 1) Accountability has a positive effect on audit judgement performance, 2) Self efficacy has a positive effect on audit judgement performance, 3) Task complexity has a negative effect on audit judgement performance, 4) Effort has a positive effect on audit performance. judgement, 5) Accountability has no effect on effort, 6) Self Efficacy has a negative effect on effort, 7) Task complexity has a positive effect on effort, 8) Efforts mediate the effect of accountability on audit judgement performance, 9) Effort does not mediate the effect of self efficacy on audit judgement performance, and 10) Efforts to mediate the effect of task complexity on audit judgement performance.
\end{abstract}

Keywords: Accountability, Self Efficacy, Task Complexity, Effort, Audit Judgement Performance.

\begin{abstract}
ABSTRAK
Tujuan dari penelitian ini adalah untuk menganalisa pengaruh Akuntabilitas, Self Efficacy, dan Kompleksitas Tugas terhadap Kinerja Audit Judgement yang dimediasi dengan Effort. Data yang digunakan dalam penelitian ini diperoleh dari Kantor Akuntan Publik (KAP) di Jakarta yang terdaftar di OJK (Otoritas Jasa Keuangan). Data dalam penelitian ini diolah dengan memakai Structural Equation Modeling (SEM) dengan uji statistik memakai Smart Partial Least Square (PLS). Objek penelitian pada pada penelitian ini adalah seluruh auditor di KAP yang terdaftar oleh OJK. Penelitian ini menggunakan metode penelitian survei dengan pengumpulan data primer menggunakan kuesioner. Hasil penelitian menunjukkan: 1) Akuntabilitas berpengaruh positif terhadap kinerja audit judgement, 2) Self efficacy berpengaruh positif terhadap kinerja audit judgement, 3) Kompleksitas tugas berpengaruh negatif terhadap kinerja audit judgement, 4) Usaha (Effort) berpengaruh positif terhadap kinerja audit judgement, 5) Akuntabilitas tidak berpengaruh terhadap usaha (effort), 6) Self Efficacy berpengaruh negatif terhadap effort, 7) Kompleksitas tugas berpengaruh positif terhadap effort, 8) Usaha memediasi pengaruh akuntabilitas terhadap kinerja audit judgement, 9) Usaha tidak memediasi pengaruh self efficacy terhadap kinerja audit judgement, dan 10) Usaha mediasi pengaruh kompleksitas tugas terhadap kinerja audit judgement.
\end{abstract}

Kata kunci: Akuntabilitas, Self Efficacy, Kompleksitas Tugas, Effort, Kinerja Audit Judgement 


\section{PENDAHULUAN}

\subsection{Latar Belakang}

Penelitian ini dilaksanakan bertujuan untuk mengetahui pengaruh antara akuntabilitas, self efficacy, dan kompleksitas tugas terhadap kinerja audit judgement dengan effort sebagai variabel intervening. Audit judgement merupakan salah satu standar auditing yang mesti dilakukan oleh seorang auditor dalam rangka melaksanakan tugas auditnya (SPAP Seksi 150).

Audit Judgement dan keputusan yang diambil harus didasarkan pada kualitas informasi yang relevan dan dapar dipercaya yang akan berdampak pada kualitas dari proses audit. Menurut Hogarth (1991) bahwa audit judgement sebagai proses kognitif yang merupakan perilaku pemilihan keputusan (Putu \& Sari, 2018). Standar Profesional Akuntan Publik (SPAP) pada seksi 341 menyebutkan bahwa audit judgment atas kemampuan kesatuan usaha dalam mempertahankan kelangsungan hidupnya harus berdasarkan pada ada tidaknya kesangsian dalam diri auditor itu sendiri terhadap kemampuan kesatuan usaha dalam mempertahankan kelangsungan hidupnya dalam periode satu tahun sejak tanggal laporan keuangan auditan.

Berdasarkan SPAP seksi 341 yang dipaparkan sebelumnya, judgement seorang auditor sangat diperlukan untuk menentukan kelangsungan hidup suatu perusahaan kedepannya, namun kinerja audito dalam memberikan audit judgement masih sangat dipertanyakan, hal ini dikarenakan cukup banyak laporan keuangan suatu perusahaan yang mendapat opini wajar tanpa pengecualian, tapi justru mengalami kebangkrutan setelah opini tersebut dikeluarkan. Selain itu, keterlibatan akuntan publik dalam memanipulasi laporan keuangan suatu perusahaan juga merupakan alasan mengapa kinerja akuntan publik dalam membuat judgement masih dipertanyakan.

Pada Tahun 2019 terdapat 3 Kantor Akuntan Publik yang mendapatkan sanksi atas kesalahan dalam mengaudit perusahaan publik di Indonesia yang merugikan pemakai laporan keuangan dan melibatkan akuntan publik yang seharusnya menjadi pihak independen seperti PT Tiga Pilar Sejatera, Tbk (AISA), PT Hanson Internasional, Tbk (MYRX), dan PT Garuda Indonesia, Tbk (GIAA).

Kasus gagal audit ini menimbulkan dampak yang sangat merugikan di masa depan. Seperti halnya tuntutan hukum, hilangnya profesionalisme, hilangnya kepercayaan publik, dan kredibilitas sosial bagi akuntan publik, serta menurunkan kepercayaan investor untuk berinvetasi dalam perusahaan yang mengalami gagal audit. Oleh karena itu sangat penting untuk meningkatkan kinerja akuntan publik ditiap-tiap KAP mengingat peran akuntan publik yang sangat urgen dan diperlukan pada kalangan dunia usaha dan bisnis. Sebagai perusahaan yang bergerak di bidang jasa, aset utama yang harus dimiliki oleh sebuah Kantor Akuntan Publik (KAP) adalah tenaga kerja yang profesional.
Kantor Akuntan Publik harus dapat mempertahankan mutu jasa audit agar dapat mempertahankan eksistensinya. Dalam mempertahankan mutu jasa audit, akuntan publik harus kontinu memperhatikan perkembangan dan kemajuan yang dialami dalam dunia usaha dan bisnis sebagai suatu pengetahuan atau pengalaman untuk menyelesaikan berbagai kesulitan dan kendala yang dialami pada saat melakuan audit laporan keuangan dalam rangka untuk menghasilkan peningkatan kinerja. Dengan demikian, KAP harus mengetahui dan memahami tentang faktor-faktor yang dapat berpengaruhi terhadap kinerja yang dalam hal ini yaitu kinerja audit judgement, sehingga kinerja tersebut akan mencerminkan independensi dan objektivitas akuntan publik serta kualitas dari Kantor Akuntan Publik.

Penelitian yang dilakukan oleh peneliti ini memakai variabel akuntabilitas, self efficacy, kompleksitas tugas, dan usaha. Pemilihan keempat variabel ini diyakini akan mendorong auditor untuk meningkatkan kinerja audit judgement pada kantor akuntan publik (KAP) di Jakarta.

\subsection{Rumusan Masalah}

Rumusan masalah dalam penelitian ini yaitu:

1. Apakah terdapat pengaruh langsung antara akuntabilitas terhadap kinerja audit judgement ?

2. Apakah terdapat pengaruh langsung antara self efficacy terhadap kinerja audit judgement?

3. Apakah terdapat pengaruh langsung antara kompleksitas tugas terhadap kinerja audit judgement?

4. Apakah terdapat pengaruh langsung antara effort terhadap kinerja audit judgement?

5. Apakah terdapat pengaruh langsung antara akuntabilitas terhadap effort?

6. Apakah teradapat pengaruh langsung antara self efficacy terhadap effort?

7. Apakah teradapat pengaruh langsung antara kompleksitas tugas terhadap effort?

8. Apakah terdapat pengaruh tidak langsung antara akuntabilitas terhadap kinerja audit judgement melalui effort sebagai variable intervening ?

9. Apakah teradapat pengaruh tidak langsung antara self efficacy terhadap kinerja audit judgement melalui effort sebagai variable intervening ?

10. Apakah terdapat pengaruh tidak langsung antara kompleksitas tugas dengan kinerja audit judgement melalui effort sebagai variable intervening? 


\section{LANDASAN TEORI DAN HIPOTESIS}

\subsection{Landasan Teori}

\subsubsection{Teori Kebutuhan Berprestasi}

David C. McClelland dalam teori motivasinya mengemukakan adanya tiga macam kebutuhan manusia, salah satunya adalah need for achievement, yaitu dorongan untuk melebihi, mencapai standarstandar, berusaha keras untuk berhasil (Robbins, et al, 2013). Kebutuhan untuk berprestasi adalah kebutuhan untuk melakukan pekerjaan lebih baik daripada sebelumnya, selalu berkeinginan mencapai prestasi yang lebih tinggi (Mangkunegara, 2017). Orang yang berprestasi tinggi menyukai situasi-situasi dimana prestasi mereka disebabkan oleh usaha mereka sendiri dan bukan oleh faktor lainnya, seperti keberuntungan (Kreitner dan Kinicki, 2014). Seorang pegawai yang mempunyai kebutuhan akan berprestasi tinggi juga cenderung untuk berani mengambil resiko.

\subsubsection{Kinerja Audit Judgement}

Audit judgement adalah suatu proses pemeriksaan scara sistematis dan kritis yang dilakuan pihak independen terhadap laporan keuangan untuk memberikan pendapat mengenai kewajaran laporan keuangan tersebut (Sukrisno, 2017). Judgment merupakan aktivitas pusat dalam melaksanakan pekerjaan audit. Ketepatan judgment yang dihasilkan oleh auditor memberikan pengaruh dalam menyelesaikan kesimpulan akhir yang dihasilkan oleh auditor. Auditor bertugas untuk memberi penilaian tentang keadaan keuangan dalam perusahaan sehingga dibutuhkan audit judgment dimana auditor mengumpulkan bukti dalam waktu yang berbeda dan mengintegrasikan informasi dari bukti tersebut (Sinaga, 2019) . Audit judgement diperlukan pada setiap tahapan dalam proses audit atas laporan keuangan yaitu, penerimaan perikatan, perencanaan audit, pelaksanaan pengujian audit dan pelaporan audit (Mulyadi, 2014).

Menurut Jamilah, et al. (2007) dalam (Sinaga, 2019) bahwa audit judgment adalah kebijakan auditor dalam menentukan pendapat mengenai hasil auditnya yang mengacu pada pembentukan suatu gagasan, pendapat atau perkiraan tentang suatu objek, peristiwa, status, atau jenis peristiwa lainnya

\subsubsection{Akuntabilitas}

Akuntabilitas adalah mempertanggungjawabkan pengelolaan sumber daya serta pelaksanaan kegiatan suatu entitas pelaporan yang dipercayakan kepada entitas pelaporan dalam mencapai tujuan yang telah ditetapkan secara periodik (Tanjung, 2014). Menurut Tetclock (1984) (Sinaga, 2019) bahwa akuntabilitas sebagai bentuk dorongan psikologi yang membuat sesorang berusaha mempertanggung- jawabkan semua tindakan dan keputusan yang diambil kepada lingkungannnya.

Sementara itu, menurut Libby dan Luft (1993), Cloyd (1997) dan Tan dan Alison (1999) (dalam Sinaga, 2019) terdapat tiga indikator yang dapat digunakan untuk mengukur akuntabilitas individu. Pertama, seberapa besar motivasi mereka untuk menyelesaikan pekerjaan tesebut. Kedua, seberapa besar usaha (daya pikir) yang diberikan untuk menyelesaikan sebuah pekerjaan. Ketiga, keyakinan bahwa sebuah pekerjaan akan diperiksa oleh atasannya.

\subsubsection{Self Efficacy}

Self efficacy (efikasi diri) menurut Bandura, 1997) dalam (Herliansyah, 2017) merupakan kepercayaan seseorang tentang kemampuannya untuk mengatur dan melaksanakan tindakan yang dibutuhkan untuk mencapai tingkat kinerja yang diharapkan. Self efficacy dinyatakan sebagai kepercayaan seseorang bahwa dia dapat menjalankan sebuah tugas pada sebuah tingkat tertentu, adalah salah satu dari faktor yang mempengaruhi aktifitas pribadi terhadap pencapaian tugas. Self efficacy (efakasi diri) adalah persepsi/ keyakinan tentang kemampuan diri sendiri. Self efficacy adalah kepercayaan seseorang bahwa dia dapat menjalankan sebuah tugas pada sebuah tingkat tertentu, yang mempengaruhi aktifitas pribadi terhadap pencapaian tujuan.

\subsubsection{Kompleksitas Tugas}

Menurut Libby (1995) dalam (Hasnidar, 2018) bahwa kompleksitas tugas dapat dijadikan sebagai alat dalam meningkatkan kualitas hasil pekerjaan. Dengan tugas yang kompleks dan beragam akan membantu auditor lebih memahami tugas yang dikerjakannya sehingga menghasilkan suatu pertimbangan yang lebih baik.

Sisi lain, Chung dan Monroe (2001) dalam (Hasnidar, 2018) mengemukakan bahwa kompleksitas tugas dalam pengauditan dipengaruhi oleh beberapa factor, yaitu: Banyak infromasi yang tidak relevan dalam artian informasi tersebut tidak konsisten dengan kejadian yang akan diprediksikan dan Adanya ambiguitas yang tinggi, yaitu beragamnya hasil yang diharapkan oleh entitas yang diperiksa dari kegiatan pengauditan.

\subsubsection{Usaha (Effort)}

Menurut Mathis \& Jackson (2012) bahwa usaha (effort) adalah usaha yang dikeluarkan karyawan dalam melaksanakan tugsnya. Usaha yang baik dipengaruhi oleh motivasi bagus dan semangat kerja yang tinggi. Seorang karyawan harus mempunyai usaha yang tinggi terhadap pekerjaannya sehingga menciptakan suatu kinerja yang tinggi. Usaha yang dicurahkan oleh seorang karyawan dipengaruhi oleh motivasi, etika kerja, kehadiran dan rancangan tugas.

Demikian juga Mathis \& Jackson (2012) menjelaskan bahwa faktor yang mempengaruhi usaha seorang karyawan, antara lain: motivasi, etika kerja, tingkat kehadiran, dan rancangan tugas dan pekerjaan.

\subsection{Hipotesis}

2.2.1. Pengaruh Akuntabilitas terhadap Kinerja Audit Judgement melalui Effort 
Berdasarkan teori kebutuhan berprestasi yang menjelaskan bahwa orang yang memiliki kebutuhan berprestasi yang tinggi, ia akan menggerakkan dirinya agar mampu mencapai tujuan dari motifnya. Seorang auditor yang memiliki kebutuhan berprestasi yang tinggi akan memotivasi dirinya untuk mencapai prestasi yang diinginkannya. Dalam penelitian ini akuntabilitas merupakan bentuk motivasi eksternal yang akan menggerakkan seorang auditor untuk meningkatkan kinerjanya. Orang dengan akuntabilitas tinggi juga memiliki motivasi tinggi dalam mengerjakan sesuatu.

Berdasarkan beberapa hasil penelitian yang telah dilakukan, membuktikan bahwa akuntabilitas merupakan salah saktu faktor yang dapat meningkatkan kinerja audit judgement. (Putu \& Sari, 2018) dalam peneltiannya menunjukan subjek dengan akuntabilitas tinggi menghasilkan kualitas pekerjaan yang lebih baik dari pada auditor dengan akuntabilitas rendah. Bukti menunjukkan bahwa auditor dengan akuntabilitas tinggi menghasilkan kualitas pekerjaan yang lebih baik dari pada auditor dengan akuntabilitas rendah dan auditor yang memiliki akuntabilitas tinggi akan mengerahkan usaha lebih dibandingkan auditor dengan akuntabilitas rendah. Penelitian (Sinaga, 2019) juga menunjukkan bahwa tugas audit harus menyediakan beberapa mekanisme dimana usaha memediasi akuntabilitas terhadap kinerja audit judgement.

H1: Akuntabilitas Berpengaruh Langsung Terhadap Kinerja Audit judgement

H5: Akuntabilitas Berpengaruh Langsung Terhadap Effort

H8: Effort Memediasi Pengaruh Tidak Langsung Akuntabilitas Terhadap Kinerja Audit Judgement

\subsubsection{Pengaruh Self Efficacy Terhadap Kinerja Audit Judgement melalui Effort}

Self-efficacy adalah persepsi diri sendiri mengenai seberapa bagus diri dapat berfungsi dalam situasi tertentu. Self-efficacy berhubungan dengan keyakinan diri memiliki kemampuan melakukan tindakan yang diharapkan. Self-efficacy adalah penilaian diri, apakah dapat melakukan tindakan yang baik atau buruk, tepat atau salah, bisa atau tidak bisa mengerjakan sesuai dengan yang dipersyaratkan. Self-efficacy berbeda dengan aspirasi (cita-cita), karena cita-cita menggambarkan sesuatu yang ideal yang seharusnya (dapat dicapai), sedang self-efficacy menggambarkan penilaian kemampuan diri (Bandura, 1997). Berdasarkan pernyataan tersebut dapat disimpulkan bahwa, self efficacy yang dimiliki seorang auditor akan berpengaruh terhadap pilihan pertimbangan auditor (auditor judgement) untuk menghasilkan suatu keputusan.

Begitu pula dengan hasil penelitian (Tangke et al., 2020) yang mengatakan bahwa semakin tinggi self efficacy yang dimiliki seorang auditor maka akan semakin baik pula judgement yang dikeluarkan nantinya oleh auditor itu sendiri. Penelitian yang dilakukan oleh (Sinaga, 2019) menunjukkan self efficacy berpengaruh positif terhadap kinerja audit judgement. Dari beberapa penelitian di atas dapat disimpulkan bahwa, akuntan publik yang memiliki self efficacy diharapkan untuk melakukan audit judgement yang lebih baik. Namun terdapat penelitian dengan hasil yang tidak mendukung efikasi diri berpengaruh pada kinerja audit judgement yaitu penelitian.

Teori self efficacy yang dikembangkan Bandura (1997) sejalan dengan hasil penelitian ini yang menunjukkan bahwa self efficacy dapat meningkatkan audit judgment. Dalam mengerjakan tugas, auditor dihadapkan dalam berbagai hambatan dan tantangan antara lain yaitu struktur audit yang kurang baik ataupun karena tidak adanya instruksi yang tidak tepat atau jelas dari atasan (Hasnidar, 2018). Auditor dengan self efficacy yang tinggi akan lebih mudah dalam mengatasi tantangan atau hambatan yang ada, karena adanya dorongan dari diri sendiri untuk memberikan hasil yang baik sehingga ia akan mencari solusi untuk mengatasi hambatan atau tantangan tersebut secara efektif dan juga auditor dengan self efficacy yang tinggi memiliki keyakinan bahwa ia dapat menyelesaikan tugas dengan baik dalam keadaan apapun (Tangke et al., 2020).

Menurut Stajkovic, et al (1998) bahwa akuntan publik yang menganggap dirinya sangat berguna akan mengerahkan usaha yang cukup untuk menghasilkan hasil yang sukses, sehingga dalam audit tingginya self efficacy diharapkan dapat menambah usaha dalam meningkatkan kinerja audit judgement.

\section{H2: Self Efficacy Berpengaruh Langsung Terhadap} Kinerja Audit Judgement

H6: Self Efficacy Berpengaruh Langsung Terhadap Effort

H9: Effort Memediasi Pengaruh Tidak Langsung Self Efficacy Terhadap Kinerja Audit Judgement

\subsubsection{Pengaruh Kompleksitas Tugas Terhadap Kinerja} Audit Judgement melalui Effort

Menurut Libby (1995) dalam Hasnidar (2018). bahwa kompleksitas tugas dapat dijadikan sebagai alat dalam meningkatkan kualitas hasil pekerjaan. Dengan tugas yang kompleks dan beragam akan membantu auditor lebih memahami tugas yang dikerjakannya sehingga menghasilkan suatu pertimbangan yang lebih baik. Sementara itu, menurut Chung dan Monroe (2001) dalam Hasnidar (2018) mengemukakan bahwa kompleksitas tugas dalam pengauditan dipengaruhi oleh beberapa factor, yaitu: Banyak infromasi yang tidak relevan dalam artian informasi tersebut tidak konsisten dengan kejadian yang akan diprediksikan dan Adanya ambiguitas yang tinggi, yaitu beragamnya hasil yang diharapkan oleh entitas yang diperiksa dari kegiatan pengaudita. Dalam penelitian yang dilakukan oleh (Gasendi et al., 2017) menyatakan bahwa kompleksitas tugas memiliki pengaruh yang positif dan signifikan terhadap kinerja auditor dalam pembuatan audit judgement. 
Menurut Suweknyo (2016) dalam (Tangke et al., 2020) bahwa hubungan antara kompleksitas tugas dan audit judgment pada penelitian ini dapat dijelaskan dengan teori peran (Role Theory). Role ambiguity adalah salah satu elemen dari teori peran yang berkaitan dengan kompleksitas tugas yang dipandang dapat memengaruhi audit judgment.

H3: Kompleksitas Tugas Berpengaruh Langsung Terhadap Kinerja Audit Judgement

H7: Kompleksitas Tugas Berpengaruh Langsung Terhadap Effort

H9: Effort Memediasi Pengaruh Tidak Langsung Self Efficacy Terhadap Kinerja Audit Judgement

\subsubsection{Pengaruh Langsung Effort terhadap Kinerja Audit Judgement}

Usaha (effort) adalah usaha yang dikeluarkan karyawan dalam melaksanakan tugsnya. Usaha yang baik dipengaruhi oleh motivasi bagus dan semangat kerja yang tinggi. Seorang karyawan harus mempunyai usaha yang tinggi terhadap pekerjaannya sehingga menciptakan suatu kinerja yang tinggi. Usaha yang dicurahkan oleh seorang karyawan dipengaruhi oleh motivasi, etika kerja, kehadiran dan rancangan tugas. Sedangkan fakto-faktor yang mempengaruhi usaha seorang karyawan, antara lain: motivasi, etika kerja, tingkat kehadiran, dan rancangan tugas dan pekerjaan. Mathis \& Jackson (2012).

Dalam hasil penelitian yang telah dilakukan oleh (Sinaga, 2019) menunjukkan bahwa usaha (effort) berpengaruh positif dan signifikan terhadap audit judgemen. Artinya jika effort mengalami peningkatan, maka akan meningkat pula audit judgement.

Demikian juga hasil penelitian yang dilakukan (Bonner \& Sprinkle, 2002) menjelaskan bahwa besarnya usaha kognitif yang dicurahkan seseorang terhadap sebuah pekerjaan dapat dilihat dari lamanya waktu bekerja (effort duration), seberapa keras individu tersebut bekerja (effort intensity), seberapa besar perhatian yang dicurahkan untuk menyelesaikan pekerjaan (effort direction) dan seberapa banyak strategi yang dibuat untuk menyelesaikan pekerjaan (strategy development). Dalam lingkup audit, mekanisme usaha yaitu bagaimana mengerahkan usaha yang dimiliki untuk mengaudit dengan baik agar hasil audit tersebut berkualitas.

H4: Effort Berpengaruh Langsung Terhadap Kinerja Audit Judgement

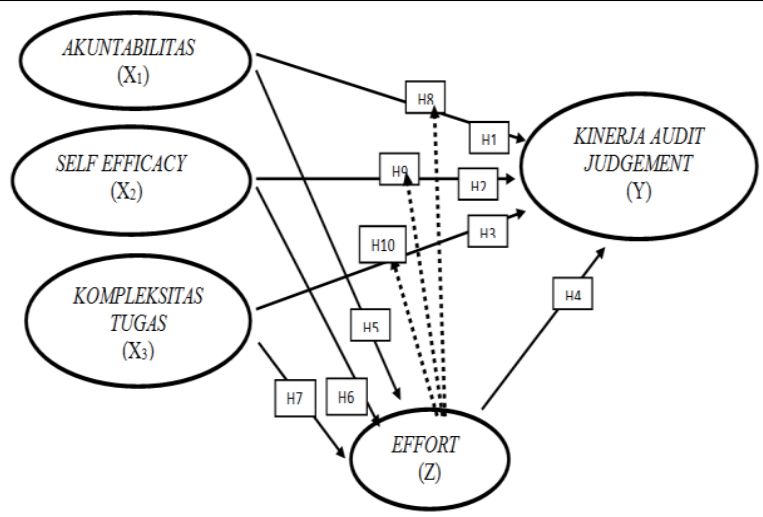

Sumber: Dikembangkan oleh peneliti Tahun 2021

\section{Gambar 1. Kerangka Teoritis}

\section{METODOLOGI PENELITIAN}

\subsection{Populasi dan Sampel}

Populasi dalam penelitian ini adalah Auditor yang berkerja di Kantor Akuntan Publik (KAP) yang berada dan terdaftar di Jakarta. Alasan menggunakan KAP di Jakarta sebagai objek penelitian, karena Jakarta merupakan kota terbesar karena merupakan ibukota negara sehingga Jakarta dinggap sebagai pusat bisnis dan pemerintahan. Jakarta diisi oleh berbagai macam sektor bisnis, terutama perekonomian yang salah satunya ditunjang oleh sektor jasa. Sedangkan sampel dalam penelitian ini meliputi auditor Partner, Manajer, Senior, dan Junior.

\subsection{Tehnik Pengumpulan Data}

Penelitian ini mengambil objek auditor yang bertugas di Kantor Akuntan Publik (KAP) yang ada di Jakarta. Metode sampling yang digunakan dalam penelitian ini adalah dengan metode probability sampling, yaitu Proportionate Stratified random sampling. Proportionate Stratified random sampling biasa digunakan pada populasi yang mempunyai susunan bertingkat atau berlapis-lapis. Teknik ini digunakan bila populasi mempunyai anggota/unsur yang tidak homogen dan berstrata secara proporsional. Dan yang menjadi responden dalam penelitian ini adalah auditor yang bekerja pada KAP di Jakarta (auditor partner, manajer, senior, dan junior).

Untuk menentukan besarnya sampel yang diambil dari populasi, maka akan digunakan rumus slovin (Sugiyono, 2013).

Ket:

$$
n=\frac{N}{1+N e^{2}}
$$

n: ukuran sampel

$\mathrm{N}$ : ukuran populasi

e: kelonggaran ketidak telitian atau derajat toleransi

Jumlah populasi ini merupakan ukuran populasi

(N) dalam rumus slovin. Derajat toleransi yang 
ditentukan sebesar $0,1 \%$ didapat berdasarkan akurasi sebesar $90 \%$ dikurangi dengan $100 \%$, sehingga memberikan hasil jumlah sampel penelitian minimal 99,99 atau sama dengan 100. Berdasarkan perhitungan sampel dengan menggunakan rumus slovin, maka diketahui jumlah sampel dalam penelitian ini adalah sebanyak 87 responden.

\subsection{Uji Kualitas Data}

Untuk menguji kualitas data dalam penelitian ini menggunakan uji validitas dan reliabilitas. Menurut Kuncoro (2013) suatu skala pengukuran disebut valid apabila melakukan apa yang seharusnya dilakukan dan mengukur apa yang seharusnya diukur. Uji validitas dalam penelitian ini, yaitu dengan menghitung korelasi antar skor tiap butir pernyataan dengan total skor atau disebut uji korelasi Pearson dengan tingkat toleransi kesalahan sebesar 0,05. Uji signifikansi dilakukan dengan membandingkan nilai $r$ hitung dengan $r$ table. Jika $r$ hitung lebih besar dari $r$ table dan nilai positif maka butir atau pertanyaan atau indicator tersebut dinyatakan valid (Ghozali, 2016).

Menurut Ghozali (2016) reliabilitas adalah alat untuk mengukur suatu kuesioner yang merupakan indikator dari variabel. Suatu kuesioner dikatakan Reliabel apabila jawaban dari seseorang terhadap pernyataan adalah konsisten atau stabil dari waktu ke waktu. Realibilitas diukur dengan menggunakan Cronbach Alpha. Variabel dikatakan reliable jika setiap pertanyaan memberikan nilai Cronbach Alpha > 0,60 (Ghozali, 2016).

\subsection{Pengajuan Hipotesis}

Pengujian hipotesis dalam penelitian ini menggunakan software Partial Least Square (PLS). Menurut Ghozali (2016) metode Partial Least Square (PLS) sebagai model persamaan strukturan berbasis variance (PLS) mampu menggambarkan variabel laten (tak terukur langsung) dan diukur menggunakan indikator-indikator (variable manifest)

PLS merupakan metode analisis yang powerful oleh karena tidak mengasumsikan data harus dengan pengukuran skala tertentu, jumlah sampel kecil. Tujuan Partial Least Square (PLS) adalah membantu peneliti untuk mendapatkan nilai variabel laten untuk tujuan prediksi (Ghozali, 2016).

\section{HASIL PENELITIAN DAN PEMBAHASAN}

\subsection{Uji Kualitas Data}

Untuk menghasilkan data dalam penelitian ini, peneliti menggunakan instrumen kuesioner yang disebarkan kepada 87 responden sebagai sampel di 12 (dua belas) Kantor Akuntansi Publik yang berada di wilayah Jakarta.

Dari hasil uji analisis statistik, maka diperoleh data nilai variabel audit judgement yaitu nilai mean sebesar 15,90 dan nilai standar deviasi 1,98. Akuntabilitas memiliki nilai mean sebesar 11,33 dengan nilai standar deviasi 1,65. Self Efficacy memiliki mean sebesar 12,03 dengan nilai standar deviasi 1,48. Sedangkan kompleksitas tugas mempunyai nilai mean sebesar 31,28 dan nilai standar deviasi 3,83. Adapun Effort memiliki nilai mean sebesar 7,89 dengan nilai standar deviasi 1,12.

Dari data nilai mean dan standar deviasi pada variabel tersebut, diketahui bahwa nilai mean lebih besar dari nilai standar deviasi, hal ini mengindikasikan bahwa data yang digunakan di dalam penelitian ini baik dan normal.

Hasil uji realibilitas terhadap variabel-variabel penelitian ini memiliki nilai cronbach's alpha $>0,70$, hal ini artinya dapat disimpulkan bahwa semua instrumen penelitian yang digunakan reliable. Variabel audit judgment memiliki nilai cronbach's alpha 0,85 , akuntabilitas 0,78, self efficacy 0,83, kompleksitas tugas 0,87 , dan effort 0,81. Uji validitas dalam penelitian ini dengan melihat nilai average variance extracted (AVE) masing-masing konstruk dimana nilainya harus lebih besar dari 0,5. Berdasarkan uji validitas yang dilakukan dapat disimpulkan jika semua variable mempunyai validitas yang baik karne memiliki nilai AVE di atas 0,5, dimana audit judgement memiliki AVE 0,59, akuntabilitas 0,54, self efficacy 0,62, kompleksitas tugas 0,57 , dan effort sebesar 0,68.

\subsection{Uji Hipotesis}

Tabel 1. Pengujian Hipotesis

\begin{tabular}{|c|c|c|c|c|}
\hline & $\begin{array}{c}\text { Original } \\
\text { Sample } \\
\text { Estimate }\end{array}$ & $\begin{array}{c}\text { Mean of } \\
\text { Subsamples }\end{array}$ & $\begin{array}{c}\text { Standard } \\
\text { Deviation }\end{array}$ & $\begin{array}{c}\text { T- } \\
\text { Statistic }\end{array}$ \\
\hline $\begin{array}{c}\text { AKUNT - } \\
\text { EFFORT }\end{array}$ & 0.265 & 0.273 & 0.202 & 1.310 \\
\hline $\begin{array}{c}\text { SELF } \\
\text { EFFICACY }- \\
>\text { EFFORT }\end{array}$ & -0.513 & -0.521 & 0.127 & 4.049 \\
\hline $\begin{array}{c}\text { KOMPL } \\
\text { TUGAS - } \\
\text { EFFORT }\end{array}$ & 0.930 & 0.934 & 0.236 & 3.938 \\
\hline $\begin{array}{c}\text { AKUNT- } \\
\text { AKINERJA }\end{array}$ & 0.104 & 0.108 & 0.056 & 1.864 \\
\hline $\begin{array}{c}\text { SELF } \\
\text { EFFICACY- } \\
>\text { KINERJA }\end{array}$ & 1.021 & 1.024 & 0.045 & 22.804 \\
\hline $\begin{array}{c}\text { KOMPL } \\
\text { TUUGAS- } \\
\text { >KINER. }\end{array}$ & -0.203 & -0.211 & 0.073 & 2.771 \\
\hline $\begin{array}{c}\text { EFFORT- } \\
\text { EKINER. }\end{array}$ & 0.092 & 0.093 & 0.037 & 2.490 \\
\hline
\end{tabular}

Sumber: Output Smart PLS 2021

Berdasarkan tabel 1 terlihat bahwa pengaruh AKUNT terhadap EFFORT positif sebesar 0.265 tapi tidak signifikan, karena nilai t-statistik lebih kecil dari nilai t-tabel $(1.310<1.66)$. Pengaruh SELF EFFICACY terhadap EFFORT negatif sebesar -0.513 dan signifikan, karena nilai t-statistik lebih besar dari nilai t-tabel (4.049> 1.66). Pengaruh KOMPLEKSITAS TUGAS terhadap EFFORT positif sebesar 0.930 dan signifikan, karena nilai t-statistik lebih besar dari nilai t-tabel (3.938 > 1.66). Pengaruh AKUNT terhadap KINERJA positif sebesar 0.104 dan signifikan, karena nilai t-statistik lebih besar dari nilai t-tabel (1.864 > 1.66). Pengaruh SELF EFFICACY terhadap KINERJA positif sebesar 1.021 dan signifikan, karena nilai tstatistik lebih besar dari nilai t-tabel (22.804 > 1.66). 
Pengaruh KOMPLEKSITAS TUGAS terhadap KINERJA negatif sebesar - 0.203 dan signifikan, karena nilai t-statistik lebih besar dari dari nilai t-tabel (2.771> 1.66), dan pengaruh EFFORT terhadap KINERJA positif sebesar 0.092 dan signifikan, karena nilai tstatistik lebih besar dari nilai t-tabel $(2.490>1.66)$.

Untuk mengetahui nilai $R$-Square setiap variabel laten dalam penelitian ini, penilaiannya menggunakan struktural model PLS. Adapaun nilai R-Square setiap variabel latennya dapat dijelaskan pada tabel di bawah ini:

Tabel 2. R-Square

\begin{tabular}{|c|c|}
\hline & R-square \\
\hline AKUNT & \\
\hline $\begin{array}{c}\text { SELF } \\
\text { EFFICACY }\end{array}$ \\
\hline KOMPL & \\
\hline EFFORT & 0.687 \\
\hline KINERJA & 0.958 \\
\hline
\end{tabular}

Dari data pada tabel tabel 2 di atas, diketahui bahwa nilai R-Square konstruk effort sebesar 0.687 dan nilai R-Square konstruk kinerja audit judgement sebesar 0.958 . Artinya bahwa semakin tinggi $R$-Square, maka akan semakin besar variabel independen tersebut dapat menjelaskan variabel dependen sehingga semakin baik persamaan strukturalnya.

Variabel effort memiliki nilai $R$-Square sebesar 0.687 , yang artinya variabel effort dipengaruhi oleh variabel akuntabilitas, self efficacy, dan kompleksitas tugas sebesar $68,7 \%$, sedangkan sisanya sebesar $32,3 \%$ dipengaruhi oleh variabel lain. Kemudian variabel kinerja audit judgement memiliki nilai $R$-Square sebesar 0.958 yang berarti kinerja audit judgement dipengaruhi oleh variabel akuntabilitas, self efficacy, kompleksitas tugas, dan effort sebesar 95,8\% sedangkan sisanya 4,2\% dipengaruhi oleh variabel yang lain.

\subsection{Pengujian Analisis Jalur}

Penggunaan analisis jalur dalam penelitian ini digunakan untuk mengetahui pengaruh langsung dan tidak langsung secara serempak atau mandiri pada setiap variabel penyebab ke variabel akibat karena peneliti ingin membandingkan berbagai jalur.
Tabel 3. Analisis Jalur/Path Coefficient

\begin{tabular}{|c|c|c|c|c|}
\hline \multicolumn{2}{|c|}{ Pengaruh Langsung } & \multicolumn{2}{|c|}{$\begin{array}{l}\text { Pengaruh Tidak } \\
\text { Lannsung }\end{array}$} & $\begin{array}{l}\text { Total Pengaruh Tidak } \\
\text { Langsung }\end{array}$ \\
\hline \multirow[t]{2}{*}{$\begin{array}{c}\text { AKUNT -> } \\
\text { KINERJA }\end{array}$} & \multirow[t]{2}{*}{0.104} & $\begin{array}{c}\text { AKUNT -> } \\
\text { EFFORT }\end{array}$ & 0.265 & \multirow[t]{2}{*}{$\begin{array}{l}\text { Jalur 1: } \\
0.104+(0.265 \times 0.092) \\
=0.128\end{array}$} \\
\hline & & $\begin{array}{c}\text { EFFORT-> } \\
\text { KINERJA }\end{array}$ & 0.092 & \\
\hline \multirow{2}{*}{$\begin{array}{l}\quad \text { SELF } \\
\text { EFFICACY - } \\
>\text { KINERJA }\end{array}$} & \multirow[t]{2}{*}{1.021} & $\begin{array}{c}\text { SELF } \\
\text { EFFICACY }> \\
\text { EFFORT }\end{array}$ & -0.513 & \multirow[t]{2}{*}{$\begin{array}{l}\text { Jalur 2: } \\
1.021+(-0.513 \times 0.092) \\
=0.974\end{array}$} \\
\hline & & $\begin{array}{l}\text { EFFORT }>> \\
\text { KINERJA }\end{array}$ & 0.092 & \\
\hline \multirow{2}{*}{$\begin{array}{l}\text { KOMPL } \\
\text { TUGAS -> } \\
\text { KINERJA }\end{array}$} & \multirow[t]{2}{*}{-0.203} & $\begin{array}{l}\text { KOMPL } \\
\text { TUGAS-> } \\
\text { EFFORT }\end{array}$ & 0.930 & \multirow[t]{2}{*}{$\begin{array}{l}\text { Jalur 3: } \\
-0.203+(0.930 \times 0.092) \\
=-0.118\end{array}$} \\
\hline & & $\begin{array}{l}\text { EFFORT }> \\
\text { KINERJA }\end{array}$ & 0.092 & \\
\hline
\end{tabular}

Sumber: Output Smart PLS 2021

Berdasarkan tabel 3 menyatakan bahwa pada jalur 1, variabel Effort (USAHA) berhasil memediasi jalur antara akuntabilitas (AKUNT) dengan Kinerja Audit Judgement (KINERJA) karena total pengaruh tidak langsung lebih besar dari pengaruh langsung. Pada jalur 2, variabel effort (USAHA) tidak berhasil memediasi jalur antara self efficacy (KEMAMP) dengan Kinerja Audit Judgement (KINERJA) karena total pengaruh tidak langsung lebih kecil dari pengaruh langsung. Kemudian pada jalur 3, variabel effort (USAHA) berhasil memediasi jalur antara kompleksitas tugas (KOMPL TUGAS) dengan Kinerja Audit Judgement (KINERJA) karena total pengaruh tidak langsung lebih besar dari pengaruh langsung.

\subsection{Pembahasan}

\subsubsection{Pengaruh Akuntabilitas terhadap Kinerja Audit Judgement}

Berdasarkan hasil yang diperoleh bahwa nilai original sampel estimate variabel akuntabilitas terhadap kinerja audit judgement sebesar 0.104 dan nilai tstatistik sebesar $1.864>$ t-tabel (1.66). Hal ini berarti hipotesis pertama diterima. Artinya bahwa akuntabilitas berpengaruh positif terhadap kinerja audit judgement.

Berdasarkan hasil tersebut, berarti relevan dengan realita di lapangan, hal ini dapat ditunjukkan dari jawaban responden pada variabel akuntabilitas banyak yang menjawab dengan skala 4 , contohnya seperti yang ditunjukkan pada indikator AK1 yang memiliki ratarata jawaban tertinggi dengan pernyataan bahwa "Saya selalu mendapat dorongan dalam bentuk motivasi dari atasan maupun senior dalam menyelesaikan setiap pekerjaan". Hal tersebut menyatakan bahwa auditor pada Kantor Akuntan Publik (KAP) di Jakarta memiliki akuntabilitas yang tinggi dalam melaksanakan pekerjaan yakni para auditor tersebut memiliki keyakinan lebih tinggi bahwa pekerjaan mereka khususnya dalam melakukan audit judgement akan didukung oleh supervisor/ manajer/ pimpinan, sehingga 
mereka akan menjadi lebih semangat dalam melaksanakan pekerjannya.

Hasil penelitian mendukung teori kebutuhan berprestasi David McClelland yang menyatakan kebutuhan akan prestasi merupakan pendorong untuk sukses dan unggul dalam kaitannya dengan serangkaian standar. Orang dengan kebutuhan akan prestasi yang tinggi berjuang untuk pencapaian prestasi pribadi dan berkeinginan untuk melakukan sesuatu yang lebih baik daripada sebelumnya (Robbin, 2016). Dalam penelitian ini akuntabilitas merupakan bentuk motivasi eksternal yang akan menggerakkan seorang auditor untuk meningkatkan kinerjanya.

Akuntabilitas adalah mempertanggungjawabkan pengelolaan sumber daya serta pelaksanaan kegiatan suatu entitas pelaporan yang dipercayakan kepada entitas pelaporan dalam mencapai tujuan yang telah ditetapkan secara periodik (Tanjung, 2014). Menurut Tetclock (1984) dalam (Sinaga, 2019) bahwa akuntabilitas sebagai bentuk dorongan psikologi yang membuat sesorang berusaha mempertanggungjawabkan semua tindakan dan keputusan yang diambil kepada lingkungannnya.

Hasil penelitian ini sesuai dengan penelitian (Sinaga, 2019) yang menyatakan bahwa akuntabilitas berpengaruh positif secara signifikan terhadap kinerja audit judgement. Dengan demikian, auditor yang memiliki akuntabilitas tinggi akan lebih berhati-hati dalam melaksanakan pekerjaannya karena mereka akan mempertanggungjawabkan semua yang telah mereka kerjakan pada atasan mereka. Ketika auditor mempertanggungjawabkan profesinya yang kerjakan, ia dapat menjadi lebih hati-hati dan teliti.

\subsubsection{Pengaruh Self Efficcay terhadap Kinerja Audit Judgement}

Berdasarkan hasil diperoleh bahwa nilai original sampel estimate variabel self efficcay terhadap kinerja audit judgement sebesar 1.021 dan nilai t-statistik sebesar 22.804 yang lebih besar dari t-tabel (1.66). Yang artinya hipotesis kedua diterima. Artinya bahwa self efficacy berpengaruh positif dan Signifikan terhadap kinerja audit judgement.

Berdasarkan data di lapangan yang terdapat dalam kuesioner, jawaban tertinggi responden pada variabel self efficacy ditunjukkan oleh indikator SE1 dengan pernyataan bahwa "Saya cenderung memilih pekerjaan dengan tingkat kesulitan sesuai dengan kemampuan yang saya miliki". Hal ini menunjukkan bahwa sebenarnya responden kurang yakin terhadap kemampuan yang dimilikinya ketika menghadapi tugas yang sulit. Menurut penelitian (Narayana \& Juliarsa, 2016) membuktikan bahwa self efficcay yang tinggi dapat meningkatkan audit judgement, hanya ketika auditor mengelola tugas-tugas yang sederhana.

Hasil Penelitian ini sejalan dengan penelitian (Sinaga, 2019) bahwa Self Efficacy berpengaruh positif dan signifikan terhadap kinerja audit judgment.. Pernyataan tersebut didukung oleh teori motivasi kerja yang menyebutkan motivasi intrinsik dipengaruhi oleh faktor seperti kebanggaan akan dirinya dapat melakukan sesuatu pekerjaan yang orang lain belum tentu melakukannya, kecintaan terhadap pekerjaan itu dan minat yang besar terhadap tugas atau pekerjaan yang dilakukan selama ini (Hamzah, 2012 ).

Hasil penelitian ini tidak sependapat dengan penelitian yang dilakukan oleh Destamara (2014) yang menunjukkan bahwa self efficacy tidak berpengaruh secara signifikan terhadap kinerja audit judgement. Dalam penelitiannya Nadhiroh menyatakan self efficacy tidak mempengaruhi kinerja lebih disebabkan pengaruh imbalan yang diberikan atas kemampuannya, walaupun auditor mempunyai self efficacy yang tinggi namun jika imbalan yang diberikan rendah maka self efficacy yang dimiliki seseorang ini tidak akan berpengaruh terhadap kinerjanya.

\subsubsection{Pengaruh Kompleksitas Tugas terhadap Kinerja Audit Judgement}

Berdasarkan hasil diperoleh bahwa nilai original sampel estimate variabel kompleksitas tugas terhadap kinerja audit judgement sebesar - 0.203 dan nilai tstatistik sebesar $2.771>$ t-tabel (1.66). Hal ini berarti hipotesis ketiga diterima. Artinya bahwa kompleksitas tugas berpengaruh negatif dan signifikan terhadap kinerja audit judgement.

Kenayataan tersebut di atas, relevan dengan kondisi di lapangan yang dapat ditunjukkan dari jawaban responden pada kompleksitas tugas banyak yang menjawab dengan skala 4 , misalnya saja pada indikator KT8 yang memiliki rata-rata jawaban tertinggi dengan pernyataan bahwa "Mampu meminimalkan ambiguitas atas beragamnya outcome (hasil) yang diharapkan oleh klien dari kegiatan pengauditan". Hal tersebut menyatakan bahwa auditor pada KAP di Jakarta bahwa auditor di Jakarta sering menghadapi ambiguitas atas hasil yang diharapkan oleh klien sehingga dapat mengganggu objektivitas dari hasil audit. Adanya pengaruh negatif tersebut memperlihatkan terdapat hubungan berlawanan antara kompleksitas tugas dengan audit judgement. Artinya semakin tinggi kompleksitas tugas akan diterima auditor, mengakibatkan semakin rendahnya audit judgement. Oleh karena itu, hipotesis ketiga dalam penelitian ini diterima, artinya bahwa kompleksitas tugas berpengaruh terhadap audit judgement.

Hasil penelitian ini selaras dengan penelitian (Ayu et al., 2014) dan (Evi et al., 2014). Hasil kedua penelitian tersebut menjelaskan kompleksitas tugas berpengaruh negatif dan signifikan terhadap kinerja audit judgement. Audit judgement akan menjadi rendah jika suatu tugas yang diberikan oleh penilaian auditor kepadanya kurang jelas bahkan terlalu sukar atau sulit, sehingga dapat membingungkan auditor tersebut. Sebagaimana menurut Bonner seperti yag dijelaskan oleh (Ayu et al., 2014) bahwa merupakan suatu dasar argumentasi yang sangat urgen untuk mengetahui suatu kompleksitas tugas dalam permasalahan lingkungan audit adalah disebabkan adanya kompleksitas tugas 
tersebut bisa berakibat terhadap kinerja audit judgement, dan terdapatnya suatu pemahaman terkait kompleksitas tugas audit yang berlainan bisa menolong para manajer untuk menyelesaikan suatu tugasnya jadi lebih baik atau suatu pelatihan dalam pengambilan tindakan suatu keputusan.

Hasil penelitian ini tidak sejalan dengan penelitian (Gasendi et al., 2017) menunjukkan bahwa variable kompleksitas tugas memiliki pengaruh yang positif dan signifikan terhadap kinerja auditor dalam pembuatan audit judgement. Hal ini dikarenakan kompleksitas audit mengacu pada pandangan individu berkenaan dengan kesukaran suatu pekerjaan audit. Sehingga terdapat seseorang auditor yang memiliki pandangan tugas audit sebagai tugas/ pekerjaan dengan kompleksitas yang tinggi atau sulit, sementara itu seseorang auditor yang lainnya ada yang memiliki pandangan atau persepsi sebagai tugas yang gampang atau mudah.

\subsubsection{Pengaruh Effort Terhadap Kinerja Audit Judgement}

Berdasarkan hasil diperoleh bahwa nilai original sampel estimate variabel usaha (effort) terhadap kinerja audit judgement sebesar 0.092 dan nilai t-statistik sebesar $2.490>$ t-tabel (1.66). Hal ini berarti hipotesis keempat diterima. Artinya bahwa usaha (effort) berpengaruh positif dan signifikan terhadap kinerja audit judgement.

Kenyataan di atas relevan dengan kondisi di lapangan yang dapat ditunjukkan dari jawaban responden pada variabel akuntabilitas banyak yang menjawab dengan skala 4, misalnya saja pada indikator U1 yang memiliki rata-rata jawaban tertinggi dengan pernyataan bahwa Usaha yang saya curahkan terlihat dari lamanya waktu saya bekerja. Hal tersebut menyatakan bahwa responden sangat menghargai wwaktu semaksimal mungkin, Ketika mereka berhasil menyelesaikan pekerjaannya seefisien mungkin mereka akan membutuhkan usaha lebih untuk mecapai tujuan tersebut. Pengaruh positif menunjukkan adanya hubungan yang searah antara usaha dapat meningkatkankualitas audit judgment, semakin tinggi dorongan psikologi/motivasi internal yang diberikan auditor dalam berupa usaha maka semakin tinggi kualitas audit judgment yang dihasilkan oleh auditor.

Penelitian ini sejalan dengan penelitian yang dilakukan (Sinaga, 2019) yang menyatakan bahwa semakin tinggi usaha (Effort) maka semakin baik hasil dari kinerja audit judgement. Dalam penelitian Cloyd (1997), Libby dan Lipe (1992), Bonner dan Sprinkle (2002) dan Sanusi et al. (2007) dalam (Akuntansi et al., 2016) dijelaskan bahwa Jumlah usaha kognitif yang dikeluarkan dalam tugas dapat ditingkatkan baik melalui lamanya upaya (effort) (misalnya bekerja lebih lama), intensitas upaya (effort) (misalnya bekerja lebih keras), atau melalui keduanya baik durasi/lamanya dan intensitas upaya. Sebagai insentif untuk meningkatkan audit judgment perform- ance, mekanisme yang dapat dirancang individu auditor untuk mengerahkan atau upaya untuk melakukannya dengan baik dalam tugas audit yang dilaksanakan. Studi empiris sebelumnya dalam akuntansi menunjukkan bahwa insentif kinerja menyebabkan individu auditor dapat meningkatkan jumlah upaya (effort) yang ditujukan untuk tugas audit.

\subsubsection{Pengaruh Akuntabilitas Terhadap Effort}

Berdasarkan hasil diperoleh bahwa nilai original sampel estimate variabel akuntabilitas terhadap usaha (effort) sebesar 0.265 dan nilai t-statistik sebesar 1.310 yang < t-tabel (1.66). Hal ini berarti hipotesis kelima ditolak. Artinya bahwa akuntabilitas berpengaruh positif, tapi tidak signifikan terhadap usaha (effort).

Kenyataan di atas relevan dengan kondisi di lapangan yang dapat ditunjukkan dari jawaban responden pada variabel akuntabilitas banyak yang menjawab dengan skala 4, misalnya saja pada indikator AK1 yang memiliki rata-rata jawaban tertinggi dengan pernyataan bahwa "Saya selalu mendapat dorongan dalam bentuk motivasi dari atasan maupun senior dalam menyelesaikan setiap pekerjaan". Hal tersebut menyatakan bahwa dorongan motivasi eksternal yang dilakukan dapat meningkatkan usaha (effort) auditor dalam menyelesaikan tugasnya. Pengaruh positif menunjukkan adanya hubungan yang searah antara akuntabilitas dapat meningkatkan usaha auditor, semakin tinggi dorongan psikologi yang diberikan auditor dalam mempertanggung jawabkan pekerjaannya maka semakin tinggi usaha yang dilakukan oleh auditor. Namun akuntabilitas bukan merupakan factor dominan dalam menentukan usaha (effort) auditor untuk menyelesaikan tugasnya Sehingga hipotesis kermpat dalam penelitian ini yang menyatakan bahwa akuntabilitas berpengaruh positif dan tidak signifikan terhadap audit judgement.

Akuntabilitas dalam penelitian tidak berpengaruh signifikan terhadap kinerja audit dikarenakan akuntabilitas bukan factor penting dalam peningkatan kinerja audit judgement atau ada indicator dalam penelitian ini yang belum maskimal dalam mengikur variable tersebut. Hail penelitian ini tidak sejalan dengan hasil penelitian yang dilakukan oleh (Sinaga, 2019) bahwa akuntabilitas mempunyai pengaruh positif dan signifikan terhadap usaha (effort).

\subsubsection{Pengaruh Self Efficacy Terhadap Effort}

Berdasarkan hasil diperoleh bahwa nilai original sampel estimate variabel Self Efficacy terhadap usaha (effort) sebesar - 0.2513 dan nilai t-statistik sebesar $4.049>$ t-tabel (1.66). Hal ini berarti hipotesis keenam diterima. Artinya bahwa Self Efficacy berpengaruh negatif dan signifikan terhadap usaha (effort).

Berdasarkan data di lapangan yang terdapat dalam kuesioner, jawaban tertinggi responden pada variabel self efficacy ditunjukkan oleh indikator SE1 dengan pernyataan bahwa "Saya cenderung memilih pekerjaan dengan tingkat kesulitan sesuai dengan kemampuan yang saya miliki". Pengaruh negatif menunjukkan adanya hubungan yang tidak searah antara self efficacy terhadap usaha yang dikeluarkan auditor, semakin 
tinggi kemampuan diri yang dimiliki oleh seorang auditor maka semakin rendah usaha yang dilakukan oleh auditor. Menurut Bandura (1997) (dalam Herliansyah, 2017) bahwa self efficacy (efikasi diri) merupakan kepercayaan seseorang tentang kemampuannya untuk mengatur dan melaksanakan tindakan yang dibutuhkan untuk mencapai tingkat kinerja yang diharapkan. Self efficacy dinyatakan sebagai kepercayaan seseorang bahwa dia dapat menjalankan sebuah tugas pada sebuah tingkat tertentu, adalah salah satu dari faktor yang mempengaruhi aktifitas pribadi terhadap pencapaian tugas. Self efficacy (efakasi diri) adalah persepsi/keyakinan tentang kemampuan diri sendiri. Self efficacy adalah kepercayaan seseorang bahwa dia dapat menjalankan sebuah tugas pada sebuah tingkat tertentu, yang mempengaruhi aktifitas pribadi terhadap pencapaian tujuan.

\subsubsection{Pengaruh Kompleksitas Tugas Terhadap Effort}

Berdasarkan hasil diperoleh bahwa nilai original sampel estimate variabel Self Efficacy terhadap usaha (effort) sebesar 0.930 dan nilai t-statistik sebesar 3.938 $>$ t-tabel (1.66). Hal ini artinya hipotesis ketujuh diterima. Artinya bahwa kompleksitas tugas berpengaruh positif dan signifikan terhadap usaha (effort).

Kenyataan di atas relevan dengan kondisi di lapangan yang dapat ditunjukkan dari jawaban responden pada variabel kompleksitas tugas banyak yang menjawab dengan skala 4, misalnya saja pada indikator KT8 yang memiliki rata-rata jawaban tertinggi dengan pernyataan bahwa mampu meminimalkan ambiguitas atas beragamnya outcome (hasil) yang diharapkan oleh klien dari kegiatan pengauditan. Pengaruh positif menunjukkan adanya hubungan yang searah antara kompleksitas tugas terhadap usaha yang dikeluarkan auditor, semakin tinggi kompleksitas tugas yang diahadapi seorang auditor maka semakin tinggi usaha yang dilakukan oleh auditor. Dalam penelitian (Hastuti \& Sundari, 2018) dijelaskan bahwa kompleksitas tugas merupakan suatu tugas yang kompleks dan rumit. Sehingga membuat para pengambil keputusan harus meningkatkan kemampuan daya pikir dan kesabaran dalam menghadapi masalah-masalah didalam tugas tersebut. Disini pengambil keputusan atau auditor pada khususnya dituntut untuk mengembangkan pola pikir kreativitas dan inovasinya agar tugas yang kompleks tersebut dapat terselesaikan dengan lancar).

Penelitian ini searah dengan penelitian yang dilakukan oleh Asiymilla (2018) yang menyatakan dimana ketika auditor dihadapkan pada kompleksitas tugas yang tinggi, maka usaha yang dikeluarkan oleh auditor pula semakin tinggi untuk menyelesaikan tugasnya dan menghasilkan hasil yang baik. Namun berbeda dengan penelitian yang dilakukan oleh (Sugiarto, 2008) dimana variabel kompleksitas yang rendah tidak berpengaruh pada variable usaha yang rendah atau tinggi.

\subsubsection{Pengaruh Akuntabilitas terhadap Kinerja Audit} Judgement yang Dimediasi dengan Effort

Berdasarkan hasil dari perbandingan pengaruh langsung dengan pengaruh tidak langsung, dimana pengaruh tidak langsung antara AK-EF-AJ lebih besar (0.128) daripada pengaruh langsung antara AK-AJ (0.104). Yang artinya hipotesis 8 diterima. Hal ini berarti bahwa effort memediasi pengaruh akuntabilitas terhadap kinerja audit judgement.

Berdasarkan data lapangan dalam kuesioner pada variabel akuntabilitas dan effort dimana auditor pada KAP di Jakarta memiliki motivasi yang tinggi yang menyebabkan mereka berusaha melakukan yang terbaik dalam menyelesaikan pekerjaannya. Auditor yang memiliki akuntabilitas yang tinggi akan meningkatkan usahanya dalam meningkatkan kinerja audit judgement, baik melalui usaha durasi (misalnya waktu bekerja lebih lama) dan intensitas usaha (contohnya kerja lebih keras). Ketika seorang auditor memiliki akuntabilitas yang tinggi (yakin bahwa pekerjannya akan diperiksa dan dikritisi oleh atasan) mereka akan lebih bertanggungjawab secara pribadi dan akan mengerahkan usaha untuk menghasilkan kinerja yang baik. Dengan demikian dapat disimpulkan bahwa, auditor termotivasi dan mengerahkan usahanya dalam bekerja ketika memiliki akuntabilitas tinggi.

Hasil penelitian ini mendukung teori kebutuhan berprestasi McClelland yang menyatakan bahwa orang yang memiliki kebutuhan berprestasi yang tinggi, ia akan menggerakkan dirinya agar mampu mencapai tujuan dari motifnya. Akuntabilitas merupakan bentuk dorongan psikologi yang membuat seseorang berusaha mempertanggungjawabkan semua tindakan dan keputusan yang diambil kepada lingkungannya (Sari \& Mardisar, 2007). Dengan demikian, auditor yang memiliki akuntabilitas tinggi, akan lebih berhati-hati dan mengerahkan usaha lebih untuk mencapai kinerja audit judgement yang baik.

Penelitian (Sinaga, 2019) yang menunjukkan bahwa dengan meningkatkan tekanan akuntabilitas maka effort para auditor juga akan mengalami peningkatan

\subsubsection{Pengaruh Self Efficcay terhadap Kinerja Audit Judgement yang Dimediasi dengan Effort}

Berdasarkan hasil dari perbandingan pengaruh langsung dengan pengaruh tidak langsung, dimana pengaruh tidak langsung antara SE-U-AJ lebih kecil (0.974) daripada pengaruh langsung antara SE-AJ (1.021). Hal ini artinya hipotesis 9 ditolak. artinya bahwa effort tidak memediasi pengaruh self efficacy terhadap kinerja audit judgement.

Berdasarkan data dilapangan yang dilihat dari jawaban kuesioner pada variabel self efficacy dan effort yang menyatakan bahwa usaha (effort) memediasi pengaruh self efficcay terhadap kinerja audit judgement auditor pada KAP di Tangerang dimana, auditor yang memiliki self efficacy yang tinggi cenderung tidak berusaha lebih keras dalam melakukan pekerjannya, 
baik melalui usaha durasi (misalnya waktu kerja lebih lama) dan intensitas usaha (contohnya bekerja lebih keras) sehingga akan mempengaruhi hasil audit judgment. Hal tersebut dapat dilihat melalui jawaban responden pada pada variabel self efficacy ditunjukkan oleh indikator SE1 dengan pernyataan bahwa "Saya cenderung memilih pekerjaan dengan tingkat kesulitan sesuai dengan kemampuan yang saya miliki”.

Effort dalam penelitian ini tidak memediasi antara Self Efficacy terhadap kinerja audit dikarenakan Effort bukan factor penting dalam memediasi self efficacy dalam peningkatan kinerja audit judgement atau ada indicator dalam penelitian ini yang belum maskimal dalam mengikur variable tersebut. Penelitian ini tidak sejalan dengan penelitian yang dilakukan oleh (Sinaga, 2019) bahwa Effort mempunyai pengaruh mediasi antara Self Efficacy terhadap Kinerja Audit Judgment. Penelitian tersebut mengganggap bahwa akuntan publik yang menganggap dirinya sangat berguna akan mengerahkan usaha yang cukup untuk menghasilkan hasil yang sukses, sehingga dalam audit tingginya self efficacy diharapkan dapat menambah usaha dalam meningkatkan kinerja audit judgement.

\subsubsection{Pengaruh Kompleksitas Tugas terhadap Kinerja Audit Judgement yang Dimediasi dengan Effort}

Berdasarkan hasil dari perbandingan pengaruh langsung dengan pengaruh tidak langsung, dimana pengaruh tidak langsung antara KT-U-AJ lebih besar (-0.118) daripada pengaruh langsung antara KT-AJ $(-0.203)$. Yang artinya hipotesis 10 diterima. Hal ini berarti bahwa effort memediasi pengaruh kompleksitas tugas terhadap kinerja audit judgement.

Berdasarkan data lapangan dalam kuesioner pada variabel kompleksitas tugas dan effort dimana auditor pada KAP di Jakarta memiliki motivasi yang tinggi yang menyebabkan mereka berusaha melakukan yang terbaik dalam menyelesaikan pekerjannya. Kenyataan tersebut sesuai dengan kondisi di lapangan yang dapat ditunjukkan dari jawaban responden pada variabel akuntabilitas banyak yang menjawab dengan skala 4, misalnya saja pada indikator U1 yang memiliki ratarata jawaban tertinggi dengan pernyataan bahwa "Usaha yang saya curahkan terlihat dari lamanya waktu saya bekerja".

Hasil penelitian ini mendukung penelitian yang dilakukan oleh Cloyd (1997) dalam (Sugiarto, 2008) dijelaskan bahwa pengaruh kompleksitas tugas terhadap kualitas audit judgement tidak dapat digeneralisasi untuk berbagai usaha. Dengan kata lain, untuk kompleksitas tugas yang rendah, usaha yang lebih oleh auditor akan berpengaruh langsung terhadap kinerjanya. Semakin besar usaha yang dicurahkan untuk memecahkan masalah, maka akan diperoleh strategi pemecahan yang lebih baik. Hal ini akan menyebabkan individu untuk mencari informasi yang lebih relevan. Oleh karena itu, meningkatnya usaha individu akan meningkatkan dampak yang lebih dalam efektifitas individu yang bekerja pada kompleksitas tugas yang rendah.

\section{KESIMPULAN DAN SARAN} berikut:

Hail penelitian ini dapat disimpulkan sebagai

1. Terdapat pengaruh positif akuntabilitas terhadap kinerja audit judgement. Artinya bahwa semakin tinggi akuntabilitas yang ada pada auditor, maka akan terjadi peningkatan kinerja audit judgement auditor.

2. Terdapat pengaruh positif Self efficacy terhadap kinerja audit judgement. Artinya bahwa semakin tinggi self efficcay yang ada pada auditor, maka akan semakin tinggi pula kinerja audit judgement.

3. Kompleksitas tugas berpengaruh negatif terhadap kinerja audit judgement. Hal ini berarti bahwa semakin tinggi kompleksitas tugas yang dihadapi oleh auditor, maka semakin rendah kinerja audit judgement yang dihasilkan.

4. Effort berpengaruh positif terhadap kinerja audit judgement. Hal ini berarti bahwa semakin tinggi usaha yang dilakukan oleh auditor maka semakin baik hasil kinerja audit judgment.

5. Tidak terdapat berpengaruh akuntabilitas terhadap effort. Artinya bahwa akuntabilitas yang ada pada auditor tidak berpengaruh untuk meningkatkan kinerja audit judgement.

6. Self Efficacy berpengaruh negatif terhadap effort. Hal ini berarti bahwa semakin tinggi self efficacy yang ada pada akuntan publik, maka akan semakin rendah effort yang dihasilkan oleh auditor.

7. Kompleksitas tugas berpengaruh positif terhadap effort. Hal ini berarti bahwa semakin tinggi kompleksitas tugas yang dihadapi oleh auditor, maka akan semakin tinggi effort yang dihasilkan.

8. Effort dapat memediasi pengaruh akuntabilitas terhadap kinerja audit judgement. Hal ini berarti auditor yang mempunyai akuntabilitas yang tinggi memiliki kecenderungan akan memfokuskan usahanya lebih keras lagi untuk meningkatkan kinerja audit judgement.

9. Effort tidak memediasi pengaruh self efficacy terhadap kinerja audit judgement. Hal ini berarti bahwa auditor yang mempuyai kepercayaan akan kemampuan dirinya yang tinggi tidak bepengaruh dalam peningkatan usaha (effort) dan kinerja audit judgement.

10. Usaha dapat memediasi pengaruh kompleksitas tugas terhadap kinerja audit judgement. Hal ini berarti bahwa tingkat kompleksitas tugas yang ada pada auditor akan mejadikan auditor memfokuskan usahanya untuk meningkatkan kinerja audit judgement. 
Adapun saran yang dapat diberikan untuk tindak lanjut dari hasil penelitian adalah sebagai berikut:

1. Penelitian selanjutnya dapat dilakukan dengan menambah jumlah Kantor Akuntan Publik (KAP) sebagai sampel sehingga cakupannya lebih luas, terutama di area DKI Jakarta sebagai pusat bisnis negara dan memiliki banyak KAP terdaftar di Jakarta sehingga hasil penelitiannya lebih akurat dan dapat digeneralisir.

2. Penelitian selanjutnya dapat dilakukan dengan meneliti bagaimana auditor dengan faktor motivasi dan kepribadian bisa berinteraksi dengan variabel ekternal pendukung untuk mempengaruhi kinerja auditor dalam pengambilan keputusan, seperti variabel pengetahuan dan pengalaman.

3. Penelitian selanjutnya diharapkan dapat menambah indikator untuk mengukur akuntabilitas sehingga hasil yang diperoleh dapat mempengaruhi effort dan indicator self efficacy dalam memediasi variable effort dan kinerja audit judgement.

4. Penelitian selanjutnya dapat menggunakan metode wawancara atau metode eksperimen untuk menambah tingkat keakuratan hasil penelitian dan menghindari respon yang bias.

\section{DAFTAR REFERENSI}

Aisymilla, Rika Andika. 2018. Pengaruh Tekanan Akuntabilitas, Kompleksitas Tugas Dan Effort Terhadap Audit Judgement (Studi Empiris pada Auditor di Kantor Akuntan Publik Semarang). Undergraduate thesis, Fakultas Ekonomi UNISSULA.

Bonner, S.E. and Sprinkle, G.B. 2002. The Effects of Monetary Incentives on Effort and Task Performance: Theories, Evidence, and a Framework for Research. Accounting, Organizations and Society, Vol. 27 Nos 4/5, pp. 303-45.

Bandura, A. 1997. Self-efficacy: The Exercise of Control. Freeman. New York

Destamara, Enggar Inggria. Determinasi Kinerja Auditor pada KAP di Wilayah Jawa Timur. Jurnal Akuntansi. 2015.

Evi, Kadek Ariyantini, Edy Sujana, Nyoman Ari Surya Darmawan. 2014. Pengaruh Pengalaman Auditor, Tekanan Ketaatan Dan Kompleksitas Tugas Terhadap Audit Judgment (Studi Empiris Pada BPKP Perwakilan Provinsi Bali). e-Journal S1 Ak Universitas Pendidikan Ganesha Jurnal Akuntansi Program S1. Volume 2 No.1. Universitas Pendidikan Ganesha Singaraja, Indonesia

Gasendi, Kadek Eta, Nyoman Trisna Herawati, dan Anantawikrama Tungga Atmadja. 2017. Pengaruh Kompleksitas Tugas, Orientasi Tujuan dan Self-Efficacy Terhadap Kinerja Auditor dalam Pembuatan Audit Judgement (Study Pada Kantor Akuntan Publik di Kota Denpasar). Jurnal Universitas Pendidikan Ganesha.

Ghozali, Imam. 2016. Aplikasi Analisis Multivariate Dengan Program PLS. Semarang: Badan Penerbit Universitas Diponegoro.

Hasnidar, 2018. Pengaruh Self-Efficacy, Tekanan Ketaatan Dan Independensi Auditor Terhadap Audit Judgment Dengan Kompleksitas Tugas Dan Moral Reasoning Sebagai Variabel Moderasi. Tesis. Program Magister Sains Akuntansi Fakultas Ekonomi Dan Bisnis Universitas Hasanuddin Makasar.

Herliansyah, Yudhi, 2017. Pengaruh Pengetahuan, Pengalaman Spesifik, Dan Self Efficacy Terhadap Kinerja Auditor Dengan Kompleksitas Tugas Sebagai Variabel Moderasi. Jurnal Profita Volume 10 No 1 April 2017. Universitas Mercu Buana

Hastuti, Sri dan Sundari, Siti, 2018. Locus Of Control Sebagai Varibel Moderasi Hubungan Kompleksitas Tugas Dan Kinerja Auiditor. Jurnal Keuangan dan Bisnis. DOI: 10.32524/jkb.v16i2.402. Vo. 16. Tahun 2018.

Hamzah. 2012. Teori Motivasi dan Pengukurannya: Analisis Dibidang Pendidikan. Edisi 1. Cetakan Sembilan. Jakarta: Bumi Aksara.

Kreitner, Robert dan Angelo Kinicki. 2014. Perilaku Organisasi. Edisi 9. Buku 1. Jakarta: Salemba Empat.

Kuncoro, Mudrajad. (2013). Metode Riset Untuk Bisnis dan Ekonomi. Edisi 4. Jakarta: Erlangga.

Mangkunegara, Anwar Prabu. 2017. Manajemen Sumber Daya Manusia Perusahaan, Bandung : Remaja Rosdakarya.

Mulyadi. 2014. Auditing. Edisi keenam. Jakarta: Salemba Empat.

Mathis, Robert L dan John H. Jackson, 2012. Manajemen Sumber Daya Manusia. Buku 1, Alih Bahasa: Jimmy Sadeli dan Bayu. Prawira Hie, Salemba Empat. Jakarta.

Mushin. 2016. Hubungan tekanan akuntabilitas, audit judgement performance, dan effort. Jurnal Akuntansi \& Auditing Indonesia Universitas Islam Indonesia.

Robbins, Stephen P dan Judge, Timothy A. 2013. Organizational Behavior, Terjemahan Ratna Saraswati dan Fabriella Sirait, Edition 16, Jakarta, Salemba Empat.

Sari, Ni Putu Sintya, dan Ketut Budiartha. 2018. SelfEfficacy Memoderasi Kompleksitas Tugas, Tekanan Anggaran Waktu, Independensi Terhadap Audit Judgment BPK RI Provinsi Bali. E-Jurnal Akuntansi Universitas Udayana. ISSN: 2302-8556 Vol.23.1. April (2018): 267-295. 
Sukrisno, Agoes. 2017. Auditing: Petunjuk Praktis Pemeriksaan Akuntan oleh Akuntan Publik . Buku 1, Edisi 5. Jakarta: Salemba Empat

Sari, Ni Putu Sintya, dan Ketut Budiartha. 2018. SelfEfficacy Memoderasi Kompleksitas Tugas, Tekanan Anggaran Waktu, Independensi Terhadap Audit Judgment BPK RI Provinsi Bali. E-Jurnal Akuntansi Universitas Udayana. ISSN: 2302-8556 Vol.23.1. April (2018): 267-295

Sinaga, Andrew Joscha. 2019. Pengaruh Tekanan Akuntabilitas dan Self-Efficacy Terhadap Kinerja Auditor dengan menggunakan Effort Sebagai Mediasi. Junal Ilmiah Mahasiswa Universitas Surabaya Vo. 18 No.1, Surabaya

Sugiyono. 2013. Metode Penelitian Bisnis. Edisi 17. Jakarta: Alfabeta.

Sari, Ria Nelly, Diani Mardisar, dan Rita Anugerah. 2015. A Study on Audit judgement Performance: The Effect of Accountability, Effort, Ana Task Complexity. Department of Accounting, University of Riau.

Narayana, Anak Agung Surya dan Gede Juliarsa, 2016. Kompleksitas Tugas Sebagai Pemoderasi Pengaruh Orientasi Tujuan Dan Self-Efficacy Pada Audit Judgment. Jurnal Ilmiah Akuntansi dan Bisnis, Vol. 11, No. 1, Januari 2016. Universitas Udayana (Unud), Bali, Indonesia

Tanjung. Abdul Hafiz. 2014. Akuntansi, Transparansi, dan Akuntabilitas Keuangan Publik.Yogyakarta: BPFE UGM.

Tangke, Paulus, Suwandi Ng, Erica Tungabdi, 2020. Pengalaman, Kompleksitas Tugas Dan Self Efficacy Sebagai Determinan Skeptisisme Profesional Untuk Membentuk Audit Judgment. Indonesian Journal of Accounting and Governance Vol. 4, No. 2, December 2020. Universitas Atmaja.

Wijayantini, K. A. S., Gede, A. Y., dan Anantawikrama, T. A. Pengaruh Tekanan Ketaatan, Kompleksitas Tugas, dan Self Efficacy Terhadap Audit judgement. Journal Universitas Pendidikan Ganesha Volume. 2 No:1 